УДК $37.011 .3(430): 37.036$

DOI:

Оксана Сторонська, кандидат педагогічних наук, доиент кафедри порівняльної педагогіки та методики викладання іноземних мов Дрогобицького державного педагогічного університету імені Івана Франка

\title{
ІДЕЇ ДИТИНОЦЕНТРИЧНОї ОСВІТИ В РЕФОРМАТОРСЬКІЙ ПЕДАГОГІЦІ НІМЕЧЧИНИ
}

Статтю присвячено розгляду німецького педагогічного реформаторського руху кіния ХІХ - початку XX cm. Ï̈ безпосередньою метою є історико-педагогічний аналіз ідей дитиноцентричної освіти в реформаторській педагогіиі Німеччини. У результаті досягнення мети розглянуто передумови виникнення $i$ поширення ідей дитиночентричної освіти в педагогічній теорії і шкільній практиці Німеччини у вказаний історичний період, висвітлено міркування відомих німецьких педагогів-реформаторів (Ф. Гансберга, Л. Гурліта, Г. Шаррельмана та ін.) щодо навчання і виховання молодого покоління на засадах дитиноцентризму, констатовано їх суголосність із сучасними освітніми тенденціями.

Ключові слова: реформаторська педагогіка Німеччини; дитиночентрична освіта; концептуальні засади навчання і виховання; методологічні підходи до освіти.

Jim. 10.

Oksana Storonska, Ph.D.(Pedagogy), Associate Professor of the Comparative Pedagogy and Methods of Foreign Language Teaching Department Drohobych Ivan Franko State Pedagogical University

\section{THE IDEAS OF CHILD-CENTERED EDUCATION IN THE REFORM PEDAGOGY OF GERMANY}

The article is devoted to the consideration of the German pedagogical reform movement of the late XIX $X^{\text {th }}$ early $X X^{\text {th }}$ centuries, which is distinguished by the uniqueness of scientific and pedagogical ideas and the originality of school educational practices. Its purpose is the historical and pedagogical analysis of the basic principles of the concepts of child-centered education in the reform pedagogy of Germany, the cornerstone of which is the recognition of a child's personality as the greatest value and centre of the whole educational process. The achievement of the outlined goal included the analysis, interpretation, synthesis of scientific literature on the research problem, the works of well-known German educators-reformers (F. Hansberg, L. Gurlitt, G. Charrelman, etc.) concerning the education and upbringing of the young generation on the basis of child-centrism.

First of all, the article considers the prerequisites for the emergence and spread of child-centered education ideas in pedagogical theory and school practice in Germany in the specified historical period, characterizes the peculiarities of the theory and practice of school education in the country. In the process of further research we hightlight the basic principles of the concepts of child-centered education, developed by prominent German reformers F. Hansberg, L. Gurlitt, G. Charrellman. On the basis of their works analysis we reveal the above-mentioned educatorsreformers' opinions on the key problematic aspects of that time school and summarize their suggestions and recommendations how to overcome problems. The conducted research gives grounds for evaluating the German reform pedagogy of the late XI $X^{\text {th }}$ - early XX $X^{\text {th }}$ centuries not only as a fundamental heritage of the past, but also as a true treasure of valuable ideas and solutions for contemporary problems of education and upbringing of young generations.

Keywords: reform pedagogy of Germany; child-centered education; conceptual principles of education; methodological approaches to education.

$\Pi$ остановка проблеми. Початок XXI ст. позначений докорінними трансформаціями сфері освіти, інтенсивними пошуками інноваційних підходів до навчання і виховання, переосмисленням прогресивної педагогічної думки та досвіду минулого. В сучасних умовах українські та зарубіжні педагоги активно звертаються до здобутків реформаторського педагогічного руху рубежу XIX-XX ст., що не втратили своєї цінності та актуальності й у наш час. Серед розмаїття напрямів і течій цього руху унікальністю науково- педагогічних ідей, неординарністю шкільних освітніх практик вирізняється реформаторська педагогіка Німеччини, наріжним каменем якої $є$ визнання особистості дитини найбільшою цінністю і центром усього освітнього процесу. Німецька педагогіка реформ кінця XIX - початку XX ст. це не лише фундаментальна спадщина минулого, а й справжня скарбниця цінних ідей і рішень для сучасних проблем освіти та виховання молодих поколінь.

Аналіз останніх досліджень і публікацій. 


\section{ДДЁ̈ ДИТИНОЦЕНТРИЧНОЇ ОСВІТИ В РЕФОРМАТОРСЬКІЙПЕДАГОГЩІНІМЕЧЧИНИ}

Творчі напрацювання видатних педагогівреформаторів Німеччини привертають значну дослідницьку увагу українських учених. У сучасній вітчизняній науково-педагогічній літературі грунтовно проаналізовано педагогічні концепції Г. Кершенштайнера, Г. Літца, П. Наторпа, П. Петерсена, Р. Штайнера та ін. (I. Дичківська [4], Г. Кемінь [5], А. Малько [6], О. Титаренко [7], В. Усачов [8] та ін.). Водночас здійснений аналіз наукової літератури засвідчує, що цінні здобутки німецької реформаторської педагогіки досліджені ще недостатньо повно. Зокрема, викликають інтерес концепції дитиноцентричної освіти німецьких педагогівреформаторів (Ф. Гансберга, Л. Гурліта, Г. Шаррельмана та ін.), в межах яких вона визначається основним засобом формування гуманної, творчої, активної і самостійної особистості як найвищої цінності суспільства.

Мета статті полягає в історико-педагогічному аналізі ідей дитиноцентричної освіти в реформаторській педагогіці Німеччини кінця XIX - початку XX ст.

Виклад основного матеріалу. Зростаюча криза суспільного буття у Німеччині на зламі XIX-XX ст., загострення проблем особистості в нових умовах життя і праці викликали потребу в перегляді тогочасної теорії і практики освіти. У той час питання оновлення форм, методів і змісту освіти, які б дали змогу особистості не тільки усвідомлювати соціокультурні зміни, що відбуваються, а й розширили б можливості для іiі самоактуалізації, стають основним об'єктом міркувань, роздумів, дискусій у німецькому науковопедагогічному просторі. У результаті цього виникла ціла низка дитиноцентричних, особистісноорієнтованих концепцій навчання та виховання.

Спираючись на теорію природовідповідного виховання Ж.-Ж. Руссо та Й.-Г. Песталоцці, автори цих концепцій (Ф. Гансберг, Л. Гурліт, Г. Шаррельман та ін.) невтомно доводили, що планомірне, систематичне навчання і виховання дітей за заздалегідь розробленими програмами суперечить природним закономірностям їх розвитку, тому організацію педагогічного процесу, на їхню думку, треба будувати виходячи 3 інтересів дітей, які виникають безпосередньо в процесі їх діяльності. Протестуючи проти засилля формалізму в школі, вони пропонували відмовитися від шаблонних навчальних планів і програм та взяти за основу освітньо-виховного процесу вільну творчість вчителя й учнів.

Особливо яскраве та повне осмислення цих питань здійснене в працях німецького педагогановатора Г. Шаррельмана, який переконував, що вплив школи на формування молодого покоління має виявлятися передовсім у задоволенні “...невтомної жаги нинішнього юнацтва до духовної, культурної свободи” [9, 32]. Відомий педагог наполегливо закликав замінити муштру та жорстку регламентацію шкільного життя самодіяльністю дітей, вихованням їх характеру гуманними способами. Він неодноразово стверджував, що найбільшими недоліками традиційного шкільного навчання $є$ позбавлення школярів можливостей іти власним шляхом і відсутність індивідуального підходу до дітей.

У своїх роботах ("У лабораторії народного вчителя. Досвід наочного навчання”, “Жива віра у викладанні та бесіді з дітьми та юнацтвом” та ін.) педагог вказував на необхідність подолання шаблонності та рутинності процесів виховання і навчання, відмови від звичного ігнорування особливостей дитячої природи. Зокрема він писав: “Офіційна школа не дає свободи та не вивчає дитячу природу, таким чином обмежуючи і можливості вчителів у вивченні й усвідомленні індивідуальних особливостей учнів" $[10,11]$.

Ідеї про виховання і навчання учня як суб'єкта, здатного від природи до активної пізнавальної діяльності, склали підгрунтя ключового методичного положення Г. Шаррельмана - у пізнанні явищ дійсності, у дослідженні навколишнього світу діти мають бути вільними та йти власним шляхом. Педагог стверджував, що метою вивчення будь-якого шкільного предмету має бути пробудження інтересу дитини до самостійного дослідження, що сприяє розвитку “творчого мислення”. Для забезпечення цієї свободи розвитку, самостійності дитини в навчанні та вихованні педагог-реформатор рекомендував активно використовувати методи індивідуального викладання для вчителя і самостійного вибору навчального матеріалу для дитини, шукати розв'язок глибоких питань у спільній розмові 3 дитиною, спонукати дітей до активності, виховувати в них незалежність і самостійність.

3 огляду на те, що початок XX ст., за словами Г. Шаррельмана, характеризується рухом суспільства від неволі до свободи, він закликав розвивати в молодого покоління як внутрішню (духовну), так і зовнішню (культурну, політичну) свободу, скеровувати вплив школи на пробудження у вихованців непереборного прагнення до активного, повноцінного духовного, політичного, культурного життя: “...наше завдання виховувати в дитині незалежність, внутрішню й зовнішню свободу, самосвідомість, творчість, а також негативне ставлення до всього антикультурного" $[9,58]$. 


\section{ДДЕЇ ДИТИНОЦЕНТРИЧНОЇ ОСВІТИ В РЕФОРМАТОРСЬКІЙПЕДАГОГЩІНІМЕЧЧИНИ}

Схожі підходи в переосмисленні теорії і практики традиційної шкільної освіти Німеччини на зламі XIX-XX ст. спостерігаємо і в педагогічній концепції Л. Гурліта, основні ідеї якого представлені у працях “Про виховання", “Проблеми загальної єдиної школи” та ін. Вихідним пунктом усіх його міркувань $\epsilon$ переконання у відмінності природи дитинства i дорослості. Зокрема. він стверджував: “Ми повинні привчити себе до думки, що діти - не гірші, ніж дорослі. Вони тільки пізніше народилися, $\epsilon$ молодшими і біднішими на досвід. Але бути дитиною - це не недолік і аж ніяк не провина" [2, 21]. На його думку, дитина не зобов'язана бути нарівні з дорослою особистістю чи бути схожою на неї. Дитина має лише один обов'язок розвиватися відповідно до своєї природи, середовища і часу.

Відповідно до міркувань Л. Гурліта, освіта не має спрямовуватися винятково на досягнення раціоналістичних цілей, а повинна виявляти і спрямовувати творчу силу й активність кожної дитини, допомагаючи їй розвиватися індивідуально, з урахуванням природних задатків. А тому мета навчально-виховної діяльності, на його думку, полягає у розвитку “. . . всіх позитивних схильностей і сил, дарованих дитині природою”. Роль же педагога при цьому зводиться до того, щоб спостерігати і допомагати повноцінному вияву і розвитку цих сил і здібностей з огляду на особливості поточного моменту, а не на наукові теорії, інструкції, програми і заздалегідь написані плани [3, 94].

Л. Гурліт рішуче засуджував “насильницьке годування” дитячого розуму часто непотрібними i навіть абсолютно зайвими теоретичними знаннями. Заперечуючи жорсткість систематичних навчальних занять, він протиставляв їм різноманітні вільні види діяльності, в процесі яких якнайкраще чином виявляється і реалізується творчий потенціал зростаючої людини, розвиваються іiі духовні сили. Зокрема, систематичні заняття в народній школі, на його думку, варто замінити фізичною культурою, іграми, бесідами, творчими роботами, тобто всім тим, що виховує незалежність суджень, самостійність і творчість дій. На противагу систематичному предметному навчанню, традиційному змісту навчальних програм німецьких шкіл Л. Гурліт висунув на передній план ідею естетичного виховання і заняття різними видами ручної праці.

Відомий німецький педагог-новатор наголошував: “. .. важливо, щоб діти багато бачили та переживали для того, щоб вони могли сформувати свій власний світогляд, а не запозичили його готовим з чужих слів ...потрібно дати їм матеріал для побудови свого духовного світу, який би був результатом їхньої власної роботи, щоб вони вклали в його створення всі свої сили і почуття ...слід захистити їх від книжкового знання, від абстрактних промов, від порожніх слів ...діти мають радіти своєму дитинству від усього серця і вважати цю радість своїм людським правом" $[2,144]$.

Подібні ідеї знайшли грунтовне висвітлення і в працях німецького педагога Ф. Гансберга. Зокрема, у роботі “Основні ідеї сучасної педагогіки” автор розмірковує над необхідністю шкільної реформи в Німеччині на початку XX ст., над іiі наслідками, потенційними небезпеками та ймовірними досягненнями. У згаданій праці педагог порівнює та визначає переваги і недоліки двох напрямів навчання - традиційного трудового, спрямованого на освоєння дітьми ремесла, і творчого, що передбачає надання дитині можливості самостійно творити, реалізовуючи свій природний потенціал.

Так, Ф. Гансберг пише: “Шкільна реформа, яка протягом декількох років так сильно хвилювала багатьох, мабуть, увійшла в нове русло. Боротьба ведеться 3 двох боків: на першому стоять прибічники практичного навчання ремесла, а на іншому - поборники переходу від теперішнього механічного навчання до продуктивної, творчої розумової роботи; з одного боку, борються за зовнішню реорганізацію шкільної справи, за перетворення школи в місце для більш бадьорої і жвавої діяльності в усіх сферах, доступних для учнів, з іншого боку, відстоюють таку реформу навчання, яка ставила б собі метою будити всі духовні сили дитини, культивувати та розвивати їх у творчій роботі" $[1,113]$.

Будучи прихильником другого напряму, педагог-новатор уважав засадничими такі принципи навчання і виховання дітей, як: свобода розкриття неповторної особистості дитини в освітньому процесі та розвитку усіх iĭ сил і здібностей; природовідповідність, що передбачає урахування природних, індивідуальних нахилів та інтересів дітей, їх вікових особливостей, що, своєю чергою, зумовлює необхідність опори на життєвий досвід, емоції, інтерес учня; культуровідповідність, який орієнтує на становлення особистості в процесі засвоєння загальнолюдських і національних культурних надбань, перетворення їх на особистісні цінності [1].

Висновки. Розробка дитиноцентричних концепцій $\epsilon$ значним внеском німецьких педагогівреформаторів (Ф. Гансберга, Л. Гурліта, Г. Шаррельмана та ін.) у світову гуманістичну 
педагогіку. Спільність їх педагогічної позиції полягає у відмові від авторитаризму традиційної школи на усіх їі рівнях унаслідок недостатньо гуманного ставлення до дитини, низької ефективності навчальних методик та утвердженні дитини головною цінністю освітнього процесу. Аналіз їхніх праць дає підстави констатувати, що під розвитком особистості вони розуміли зміни, які відбуваються у ній під впливом зовнішніх і внутрішніх чинників, в результаті яких відбувається зростання фізичних і психічних сил, переростання психічних станів у риси особистості, становлення індивіда як самостійної істоти. Оскільки природний процес розвитку фізичних і духовних сил протікає нерівномірно й суперечливо, за їхніми переконаннями, він має регулюватися вихованням і самовихованням відповідно до інтересів суспільства й особистості.

Представники німецької дитиноцентричної педагогіки (Ф. Гансберг, Л. Гурліт, Г. Шаррельман та ін.) проголошували необхідність уважного, бережливого ставлення до особистості та вимагали докорінної зміни підходів до дитини і дитинства не лише в педагогічній науці, а й у суспільстві загалом. Розумінню дитини з погляду певного ідеалу дорослих вони протиставляли сприйняття особистості як носія успадкованих якостей, основи яких виявляються в дитинстві, визнання права дитини на власний розвиток, ідеали, помилки. Найефективнішим шляхом забезпечення прав дитини автори дитиноцентричних освітніх концепцій вважали перегляд дорослими вимог щодо дітей i перенесення центру ваги на власні обов'язки.

Перспективи подальших досліджень вбачаємо у вивченні впливу німецької реформаторської педагогіки кінця XIX - початку XX ст. на сучасну освітню практику та окресленні перспектив використання позитивних здобутків i напрацювань іiі представників в умовах сьогодення.

\section{ЛІТЕРАТУРА}

1. Гансберг Ф. Основные идеи современной педагогики. Русская школа. 1914. №3. С. 112-119.

2. Гурлитт Л. О воспитании. Санкт-Петербург, 1911. $173 \mathrm{c}$.

3. Гурлитт Л. Проблемы всеобщей единой школы. Санкт-Петербург, 1919. 115 с.

4. Дичківська I. Інноваційні ідеї європейської реформаторської педагогіки ХХ століття. Нова педагогічна думка. 2010. № 4. С. 6-9.

5. Кемінь Г. Теорія і практика “нового виховання” у західноєвропейській педагогіці (кінець XIX - середина XX століття). Дрогобич : Коло, 2004. 124 c.

6. Малько А. Розвиток теорії і практики соціальної педагогіки Г. Кершенштайнером. Педагогіка, психологія та медико-біологічні проблеми фізичного виховання і спорту. 2002. № 19. С. 49-57.

7. Титаренко О. Соціальне виховання та освіта у соціально-педагогічному проекті П. Наторпа. Молодь іринок. 2008. № 1 (36). С. 126-128.

8. Усачов В. Вальдорфська педагогіка: Рудольф Штейнер і його школа. Гілея. 2013. № 72. С. 757-763.

9. Шаррельман Г. В лаборатории народного учителя. Петроград : Школа и Жизнь, 1916. 72 с.

10. Шаррельман Г. Живая вера в преподавании и беседы о жизни с детьми и юношеством. Москва, 1914. $96 \mathrm{c}$.

\section{REFERENCES}

1. Gansberg, F. (1914). Osnovnye idei sovremennoy pedagogiki [The main ideas of modern pedagogy]. Russian school. Vol. 3. pp. 112-119. [in Russian].

2. Gurlitt, L. (1911). O vospitanii [About education]. Saint Petersburg, 173 p. [in Russian].

3. Gurlitt, L. (1919). Problemy vseobshchey edinoy shkoly [The problems of a general unified school]. Saint Petersburg, 115 p. [in Russian].

4. Dychkivska, I. (2010). Innovatsiini idei yevropeiskoi reformatorskoi pedahohiky XX stolittia [Innovative ideas of European reform pedagogy of the XX century]. New pedagogical thought. Vol. 4. pp. 6-9. [in Ukrainian].

5. Kemin, H. (2004). Teoriia i praktyka "novoho vykhovannia" u zakhidnoievropeiskii pedahohitsi (kinets XIX - seredyna XX stolittia) [The theory and practice of "new upbringing" in Western European Pedagogy (the end of the XIX - the middle part of the XX century)]. Drohobych, $124 \mathrm{p}$. [in Ukrainian].

6. Malko, A. (2002). Rozvytok teorii i praktyky sotsialnoi pedahohiky H. Kershenshtainerom [The development of theory and practice of social pedagogy by G. Kerschensteiner]. Pedagogy, psychology and medical and biological problems of physical education and sport. Vol. 19. pp. 49-57. [in Ukrainian].

7. Tytarenko, O. (2008). Sotsialne vykhovannia ta osvita u sotsialno-pedahohichnomu proekti P. Natorpa [Social education in the socio-pedagogical project of P. Natorp]. Youth \& market. Vol. 1 (36). pp. 126-128. [in Ukrainian].

8. Usachov, V. (2013). Valdorfska pedahohika: Rudolf Shteiner i yoho shkola [Waldorf pedagogy: Rudolf Steiner and his school]. Gilea. Vol. 72. pp. 757-763. [in Ukrainian].

9. Sharrelman, G. (1916). V laboratorii narodnogo uchitelya [In the laboratory of a public teacher]. Petrograd, 72 p. [in Russian].

10. Sharrelman, G. (1914). Zhivaya vera v prepodavanii i besedy o zhizni s detmi i yunoshestvom [Living faith in teaching and conversations about life with children and youth]. Moscov, 96 p. [in Russian].

Стаття надійшла до редакції 15.12.2020

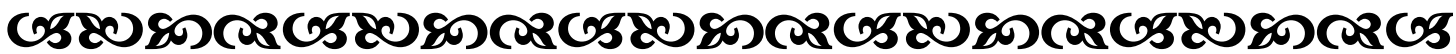

